\title{
PROF. DR. RADU CIUCEANU - AN ICONIC FIGURE OF THE ANTI-COMMUNIST RESISTANCE OR THE SURVIVAL PARADOX IN THE ROMANIAN GULAG: SUFFERING TRANSFIGURED INTO LIGHT
}

\begin{abstract}
Alin ALBU*
Abstract: Prof. Dr. Radu Ciuceanu ${ }^{1}$ is one of the last representatives of the anti-communist resistance struggle and one of the few survivors of the Pitești experiment, who, for political reasons, suffered detention and reeducation and extermination methods experienced in the Romanian Gulag. After serving 15 years in prison because he opposed the installation of the communist regime in Romania, he was released. However, post-incarceration, he had to endure systematic tracing of the former political prisoners (considered a futile social group) by the famous informative tracing file of Security. Since 1989, he has been actively involved in Romanian public life, being part of the first postrevolutionary government and supporting the configuration of a postrevolutionary elite and paradigm for the political, social and cultural reconstruction of Romania. Radu Ciuceanu is now the director of the National Institute for the Study of Totalitarianism of the Romanian Academy. His scientific work represents a significant contribution to the reconstruction of the history of totalitarianism during the communist period in Romania.
\end{abstract}

Keywords: Radu Ciuceanu, totalitarianism, communism, political prisoner, historian.

*PhD, Rev., Assistant Professor, Faculty of Theology, "1 Decembrie 1918” University, Alba Iulia, Romania.

${ }^{1}$ LAUDATIO held on the occasion of awarding the title Doctor Honoris Causa of the "1 December 1918" University in Alba Iulia, the Faculty of Theology, to Professor Dr. Radu Ciuceanu within the "International Symposium on Science, Theology, and Arts”, Alba Iulia, May 9, 2017 (short version). 


\section{Preliminaries}

Year 2017 is the commemorative year of the defenders of Orthodoxy during communism, when we commemorate the victory of normality, lucidity and integrity against depersonalization and brutalization which were subtly proposed or brutally imposed by communism.

Celebrating Professor Radu Ciuceanu today, "an insider, but also a survivor of the communist carceral universe", and an outstanding historian, we acclaim not only a man and a career, but also his testimony and the testimony of his generation for the next generations. We honor a life not only for its biological victory, but especially for its spiritual endurance.

Prof. Dr. Radu Ciuceanu "is a direct witness to everything that happened in this country, being not just a spectator, but an actor", who was actively involved in events, while others accepted their fate, having an attitude of resignation ${ }^{3}$. He is also an erudite researcher. His scientific activity represents an essential contribution to the reconstruction of the history of totalitarianism during communism in Romania.

\section{Biographical data}

Professor Radu Ciuceanu was born on April 16, 1928, in Arad. In 1947, at the age of 20, he became a member of The National Movement of Anti-Communist Resistance, Oltenia branch. He had "the attributes of a leader of a resistance group that were morally, willingly and patriotically assumed during the interrogation and trial process, developments proved by the criminal case of the Carlaonţ-Ciuceanu

2 Constantin BuCHET, "Între bestiar și martirologiu. Amintiri din iad. Intern şi internaţional în paradigma reeducării" (Foreword), in Radu CiUCEANU, La taină cu diavolul, Memorii V, București, I.N.S.T. (the National Institute for the Study of Totalitarianism), 2015 (http://www.marturisitorii.ro/2015/10/25/intre-bestiar-simartirologiu-amintiri-din-iad-radu-ciuceanu-la-taina-cu-diavolul-memorii-v-inst2015-cu-foto-inedite/.

3 Dr. Arh. Budisteanu despre Radu Ciuceanu, on http://www.dailymotion.com/ video/xz1jk0_dr-arh-budisteanu-despre-radu-ciuceanu_tech. 
Group and his informative tracing file"4.

In September 1948, he was arrested together with "Carlaont Lot" and investigated by the Security, Prosecution and NKVD, and in 1949 he was sentenced to 15 years in prison for "the crime of conspiracy against the social order", because together with other people he was accused of founding "a subversive organization with a terrorist character, bought weapons, ammunition and explosives in order to remove the current regime, fighting against the Soviet Union through sabotage and insurrection",5.

He fully served the sentence of imprisonment, knowing all the horrors of prisons from Craiova, Piteşti, Jilava, Văcăreşti, Târgşor, Dej and Gherla. At Văcăreşti, he miraculously escaped from assassination, as the tetanus injection which was meant for him was given to another prisoner, who died after three days in terrible pain.

The brutality of the penitentiary regime has been evoked on several occasions: "a wild pseudo-regulation that is unique in the history of the Romanian penitentiaries"; "being in jail is like being on a front line". But the most terrifying experience lived in the communist jails was the reeducation, a true "uprooting of the Romanian national being"": "you did not even have the chance to commit suicide. Many have tried but they were watched day and night"8.

Surviving in prison, not just physically, but especially spiritually, was the supreme test: "it was not a struggle for survival, but a struggle for the salvation of the soul"'.

In addition to the dramatic experience of prison, Prof. Radu

${ }^{4}$ Constantin Buchet, op. cit.

${ }^{5}$ http://www.ziaristionline.ro/2014/04/16/la-multi-ani-profesorului-radu-ciuceanu-la-86de-ani-reperele-mele-pline-de-lumina-sunt-anii-de-tinerete-cand-am-pus-mana-pearma-si-m-am-impotrivit-regimului-comunist-si-naimitilor-sai/.

6 Radu Ciuceanu, Memorii, vol. IV, at http://www.ziaristionline.ro/2013/04/16/ profesorul-radu-ciuceanu-la-85-de-ani-marturii-din-inchisori-prea-mult-intunericdoamne/

${ }^{7}$ Constantin Buchet, op. cit.

${ }^{8}$ Radu CIUCEANU, Jurnalul unui om liniştit. Nume de cod: ARTISTUL, on http://adevarul.ro/ news/societate/radu-ciuceanudaca-stalin-mai-traia-scapam-comunisti-1_50ad6c777c 42d5a66394e057/index.html.

9 Radu Ciuceanu, "Lupta pentru salvarea sufletului", in Ziarul Lumina, February 14, 2016, on: http://ziarullumina.ro/lupta-pentru-salvarea-sufletului-109340.html. 
Ciuceanu was instructed by a school of life, a form of education, a "University of Prison", because his generation had the chance to assimilate knowledge and vision from some of the incarcerated personalities of Interwar Romania: "and when we came out of jail we realised that we were already trained people, with a polar star that guided our destiny in the following years" $"$.

In 1963, after he had served the prison sentence, he was released in such a precarious state of health that he could barely stand. He confesses that he could have shortened his sentence if he had collaborated with the regime, but he had the strength to resist such compromise ${ }^{11}$.

After release, he had another two years of "civil death"12: he was put under house arrest until 1965, without receiving an ID card and the right to work - "in other words, I had no right to live" 13 . He was watched by Security.

Between 1965 and 1966, he worked as a laborer until he was employed as an archaeologist at The Institute of Archeology of The Romanian Academy (1967-1975), but he would be expelled for political reasons. After that, he worked as a curator at The Museum of History and Art from Bucharest (between 1975 and 1989).

In 1972, he graduated from the University of Bucharest, the Faculty of History, and in 1998, he obtained a doctorate in History at the "Nicolae Iorga" Institute of History of the Romanian Academy.

He wrote two studies clandestinely together with Octavian Roske and Daniel Barbu; namely, "The condition of the monument under the communist regime" and "Will Bucharest survive until 198?", which were broadcast on Radio Free Europe in 1981 and 1985.

After 1989, he initiated the Pain Memorial series, produced by

\section{${ }^{10}$ Ibidem.}

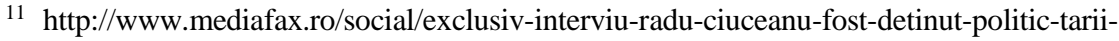
mele-pentru-care-au-murit-atatia-ii-doresc-oameni-curati-15262125;

http://www.descopera.ro/cultura/15264098-istoricul-radu-ciuceanu-tarii-mele-pentrucare-au-murit-atatia-ii-doresc-oameni-curati-interviu.

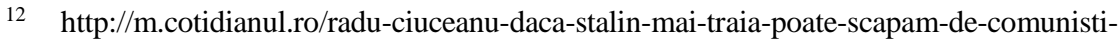
$107563 /$.

$13 \mathrm{http} / / /$ www.mediafax.ro/social/exclusiv-interviu-radu-ciuceanu-fost-detinut-politic-tariimele-pentru-care-au-murit-atatia-ii-doresc-oameni-curati-15262125;

http://www.descopera.ro/cultura/15264098-istoricul-radu-ciuceanu-tarii-mele-pentrucare-au-murit-atatia-ii-doresc-oameni-curati-interviu. 
ARS LITURGICA. From the Image of Glory to the Images of the Idols of Modernity

Romanian Television, together with Octavian Roske. In 1989, he was part of "Club 22" TV, as one of the fighters for the victory of the Romanian Revolution.

In 1993, he founded and led the National Institute for the Study of Totalitarianism (NIST) of the Romanian Academy. He currently serves as its director. The aim of the foundation is "to continue the fight against communism" "14.

During the 24 years of the NIST activity, dozens of books dedicated to the study of the anticommunist resistance and totalitarianism in Romania were published. At the beginning, they primarily published monographs and memoirs. In more recent years, they have published remarkable works of synthesis, such as the volumes of the ENCYCLOPAEDIA OF THE COMMUNIST REGIME series. The Encyclopedia deals with repression, resistance, institutions within Romania, and the structures of the Communist Party ${ }^{15}$. Written with the collaboration of nearly 100 researchers in the country, the work is "the result of the titanic work of a scientific team led by NIST"16, representing "the real report on communism from Romania"17. At the launch of the Encyclopedia, Acad. Răzvan Theodorescu expressed his conviction that only the NIST team, through this scientific approach, could globally and objectively recreate the phenomenon of communism in Romania ${ }^{18}$.

In addition to massive and diverse editing, as well as openness to cooperation and international projects, the Institute has allowed the affirmation of many young researchers, permanently keeping a tone of objectivity, without any political or ideological influence ${ }^{19}$.

In 1993, Prof. Radu Ciuceanu founded the "Archives of Totalitarianism" academic journal, which is closely connected to the

\section{${ }^{14}$ Ibidem.}

15 Octavian Roske, Prezentarea activității INST în cei 20 de ani de existență (video recording), on: http://roncea.ro/tag/constantin-buchet/.

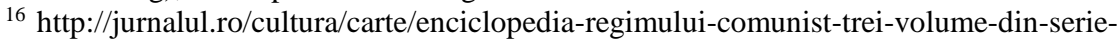
638718.html.

${ }^{17} \mathrm{http}: / /$ roncea.ro/tag/enciclopedia-regimului-comunist/.

18 http://www.ziaristionline.ro/2013/02/15/lansarea-adevaratului-raport-asupra-comunismuluidin-romania-enciclopedia-regimului-comunist-realizata-de-inst-academia-romanafoto-video-ziaristi-online/

19 Octavian Roske, Prezentarea activității INST în cei 20 de ani de existență (video recording), on: http://roncea.ro/tag/constantin-buchet/ (accessed on 8.07.2017). 
establishment of the Institute. He currently serves as the editor of this important journal.

\section{Professional deontology and moral probity}

Prof. Radu Ciuceanu has proved both his professional deontology and moral probity, the latter being confirmed not only in his current circumstances of life, but also through the recognition of others and their nomination for him to serve in important positions which require such inherent qualities (for example, the position of president of the Commission for the Investigation of Abuse and Corruption within the Romanian Parliament). Prof. Radu Ciuceanu confesses that he could have shortened his sentence of 15 years if he had given up and denied his own creed, cooperating with the regime, but he had the strength to resist ${ }^{20}$.

This strength was not dimensioned on the criterion of some philosophical or social ethos, but on strong belief in God. This affirmation is well founded. The professional quality of Prof. Radu Ciuceanu was supported by a faith lacking any artificiality: he said in an interview in 2010: "I have escaped death so many times that we can no longer speak of luck or chance, but God alone"; "If you were faithful you could retreat within yourself - 'God, give me the strength not to lose my faith!'. The moment you lost your faith it seemed normal to betray your friends, to curse your parents, anything! They brought you to the brink of insanity. I even told this to some people who did not believe"; "The secret of survival was my mother's prayers and the direct help of the divinity... Whatever I say, whatever I do, I might have become an atheist, but it is impossible for me not to admit that the divine intervention was not only redeeming but also immediate" 21 .

Thus, we do not find a mere philosophical or social ethics, a general or abstract belief, but the particular and concrete understanding, of a Romanian Orthodox Christian, who finds his identity in his Church and

20 http://www.mediafax.ro/social/exclusiv-interviu-radu-ciuceanu-fost-detinut-politictarii-mele-pentru-care-au-murit-atatia-ii-doresc-oameni-curati-15262125;

http://www.descopera.ro/cultura/15264098-istoricul-radu-ciuceanu-tarii-mele-pentrucare-au-murit-atatia-ii-doresc-oameni-curati-interviu.

21 http://adevarul.ro/news/societate/radu-ciuceanudaca-stalin-mai-traia-scapam-comunisti-1 50ad6c777c42d5a66394e057/index.html. 
ARS LITURGICA. From the Image of Glory to the Images of the Idols of Modernity

his people: "between God and the burdensome prison, his People, the Christian Church and the Family were the coordinates of his beliefs"22. For Prof. Radu Ciuceanu, "the Church was the backbone of our resistance" 23 , being one of the few intellectuals who do not deny the Christian and national component of their cultural identity, even though this now involves the risk of being labeled in one way or another.

Prof. Radu Ciuceanu loved not only the Church built by the Lord on the Cross, but also the one built by the hands of man, as he saved several churches of Bucharest from destruction, by declaring them historical monuments: Domnița Bălaşa (together with Acad. Radu Voinea), Ilie Rahova and the church from Mihăileşti - Tufa.

Prof. Radu Ciuceanu is the founding member of several associations, committees, cultural and political bodies: The Association of Former Political Prisoners from Romania (he was its vice president in 1990), The Liberal National Party, The Party of the Former Political Prisoners (he was its founding member along with general Constantin Lăţea), the founding member of the first post-revolutionary Romanian Parliament (1990).

He held the position of president or member of various committees, councils and foundations: founding member and president of The Commission for Investigation of Abuse, Corruption and for Petitions of the Romanian Parliament (2001-2004) and member of The Legal Commission of Discipline and Immunities (2000-2001), vice president (2008-2014) and then president (since 2014) of the Foundation "Romania's Pantheon", member of the Executive Bureau of The Provisional Council of National Unity (PCNU), the provisional leading body of Romania between 9 February and 18 June 1990 until after the first elections that followed the revolution of 1989.

Between 2000 and 2004 he held the position of deputy of The Greater Romania Party, and between 1990 and 1992, he was the vice president of the Chamber of Deputies. During his parliamentary activity between 2000 and 2004, in 37 sessions he spoke 38 times. In short, we should regard not only the physical presence of Prof. Radu Ciuceanu, but also his active and influential presence in public life.

22 Radu CIUCEANU: „Lupta pentru salvarea sufletului...”

${ }^{23}$ Ibidem. 


\section{Academic and professional recognition}

Today's homage, embodied in awarding the title of Doctor Honoris Causa to Professor Radu Ciuceanu, adds to the already existing recognition of his work. It pays tribute to his rich scientific, academic, administrative, political and parliamentary activity.

Thus, he has been awarded 16 prizes, distinctions and diplomas from numerous institutions, including The Romanian Academy, The Academy of Scientists from Romania, The Academy of Sciences of Moldavia - the Institute of History, State and Law, The Commission for European Integration, The Romanian Patriarchate, The Ecumenical National Center, The "Tradition of Cavalry" Association from Romania, The Cultural League for the Unity of Romanians Abroad, The Forum for Sustainable Development in Romania - Horizon 2020, The "Saints of Prison" Foundation, and The "Nicolae Malaxa" Independent Union of S.C. Republica S.A.

Prof. Radu Ciuceanu is a member of various institutions: his is honorary Member of The "Saints of Prison" Foundation (2012); honorary member of The Academy of Scientists from Romania (2013); member of The Editorial Board of "Historia" magazine; member of the Scientific Council of the Romanian Revolution Institute of December 1989; member of The Society of Heraldry; and member of the Organizing Committee of the Centenary of the Great Union: 1918-2018.

\section{Scientific activity}

Prof. Radu Ciuceanu is the author of 29 works (18 volumes as single author and 11 others, as coordinator or co-author), of more than 80 scientific articles in journals and collected volumes - since 1994, he has published articles in the "Archives of totalitarianism" journal, under the title "History as a ballast" -, as well as numerous lectures at national and international conferences ${ }^{24}$, all regarded as valuable contributions to the understanding of the repressive communist regime. He has also published numerous articles on historical monuments (monasteries, churches,

${ }^{24}$ https://lonews.ro/educatie-cultura/22658-prof-dr-radu-ciuceanu-doctor-honoris-causaal-universitatii-ovidius.html. 
ARS LITURGICA. From the Image of Glory to the Images of the Idols of Modernity architectural ensembles) and reports on archaeological excavations presented at the annual sessions organized by the Ministry of Culture and The National Commission of Archeology. He coordinated 14 research projects as director.

Among the works of Prof. Radu Ciuceanu, we mention: Memoirs, The National Movement of Resistance from Oltenia (5 volumes), The Penitentiary System from Romania, The Beginnings of the Resistance Movement in Romania (2 volumes), The Army Resistance from Bukovina (3 volumes), and The Romanian Orthodox Church under the Communist regime.

His Memoirs, published in a series of 5 volumes, are true confessions and testimonies for posterity: "our teacher does not pretend to be a logographer that recounts hearsay, but he is a chronicler of prison with Benedictine accuracy who, impetuously and dominantly, narrates what he experienced"25.

The series "is a special one in the memorialistic literature of detention in Romania because it describes with great precision and intuition both the resistance period and the process and the detention" 26 . From this point of view, unlike other works which describe the labor camps sequentially, this series provides an extended exploration of theme and chronology, providing valuable information intended to reconstruct this historical picture. It surpasses the narrative-descriptive level of similar memoirs, providing refined analyses of human experience within extreme situations. From within a refined psychological analysis, Prof. Ciuceanu reaches for lucid historical hermeneutics, combined with the emotion of personal experience. The narration becomes analysis, the description deepens into reflection (thanks to the dual capacity of the author as former prisoner and researcher), and individual memories filter and express the collective experience. Therefore, this memorialistic series doesn't represent only a personal history, but also the expression of a collective memory ${ }^{27}$.

${ }^{25}$ Constantin BucheT, op. cit.

${ }^{26}$ Prof. Roske's speech about Radu Ciuceanu, at the launch of the fourth volume of Radu Ciuceanu's memoirs, on: http://www.dailymotion.com/video/xz1j18_prof-roskedespre-radu-ciuceanu_news.

${ }^{27}$ His personal history and "the personal histories of martyrs and survivors become a collective history of a lost generation"; Constantin BUCHET, op. cit. 


\section{When the lesson is life, life becomes a lesson...}

When asked by a reporter: "What can young people learn from the experience and sufferance of their predecessors?", Prof. Radu Ciuceanu answered: "the attitude" 28 , especially "today, when we lack examples" 29. Certainly, we can all learn from Prof. Radu Ciuceanu and his generation: those born after the Second World War can admire the power to resist such a regime; those born in the "golden age" can admire the inner freedom that very few people could enjoy in that "great jail" represented by Romania at that time ${ }^{30}$ - because the lack of freedom of any kind was the greatest evil of communism! All those who have experienced the "fear of whoever and whatever" can learn bravery from him! Finally, the young generations can learn awareness, because we cannot remain ignorant or amnesic, forgetting the recent past of our parents and our grandparents! "VIVAT, CRESCAT, FLOREAT!"

\section{References}

1. CV Radu Ciuceanu, April 2015 (manuscript provided by the author).

2. Păiușan, Cristina / Ciuceanu, Radu, Biserica Ortodoxă Română sub regimul comunist, vol. I: 1945-1958, București, I.N.S.T., 2001.

\section{Web Sources}

1. BUCHET, Constantin, "Între bestiar și martirologiu. Amintiri din iad. Intern şi internaţional în paradigma reeducării” (Foreword), in Radu Ciuceanu, La taină cu diavolul, Memorii V, București, I.N.S.T. (the National Institute for the Study of Totalitarianism), 2015, on: http://www.marturisitorii.ro/2015/10/25/intre-bestiar-si-martirologiu-

http://www.mediafax.ro/social/exclusiv-interviu-radu-ciuceanu-fost-detinut-politictarii-mele-pentru-care-au-murit-atatia-ii-doresc-oameni-curati-15262125;

http://www.descopera.ro/cultura/15264098-istoricul-radu-ciuceanu-tarii-mele-pentrucare-au-murit-atatia-ii-doresc-oameni-curati-interviu. http://adevarul.ro/news/societate/radu-ciuceanudaca-stalin-mai-traia-scapamcomunisti-1_50ad6c777c42d5a66394e057/index.html

30 http://www.mediafax.ro/social/exclusiv-interviu-radu-ciuceanu-fost-detinut-politictarii-mele-pentru-care-au-murit-atatia-ii-doresc-oameni-curati-15262125;

http://www.descopera.ro/cultura/15264098-istoricul-radu-ciuceanu-tarii-mele-pentrucare-au-murit-atatia-ii-doresc-oameni-curati-interviu. 
amintiri-din-iad-radu-ciuceanu-la-taina-cu-diavolul-memorii-v-inst2015-cu-foto-inedite/, (accessed, April 6, 2017).

2. Ciuceanu, Radu, Discursul de recepție la conferirea calității de Membru de Onoare al Academiei Oamenilor de Știință din România, 5 martie 2013, on: http://roncea.ro/2013/03/06/profesorul-radu-ciuceanumembru-de-onoare-al-academiei-oamenilor-de-stiinta-din-romania-undiscurs-impresionat-o-idee-cat-o-viata-ganduri-ale-temnitei/, (accessed, April 11, 2017).

3. CIUCEANU, Radu, "Lupta pentru salvarea sufletului", in Ziarul Lumina, February 14, 2016, on: http://ziarullumina.ro/lupta-pentru-salvareasufletului-109340.html, (accessed, April 8, 2017).

4. Roske, Octavian, Prezentarea activității INST în cei 20 de ani de existență (video), on: http://roncea.ro/tag/constantin-buchet/, (accessed, April 8, 2017).

5. http://inst-idst.ro/ (accessed, April 11, 2017)

6. http://www.ziaristionline.ro/2013/09/27/profesorul-radu-ciuceanudecorat-de-patriarh-la-aniversarea-inst-de-la-academia-romanafotovideo-trinitasziaristi-online/, (accessed, April 6, 2017).

7. http://www.cdep.ro/pls/parlam/structura2015.mp?idm=71\&cam=2\&le g=2000, (accessed, April 3, 2017).

8. http://www.cdep.ro/pls/parlam/structura2015.mp?idm=71\&cam=2\&le $\mathrm{g}=2000 \&$ pag=0, (accessed, April 3, 2017).

9. http://www.mediafax.ro/social/exclusiv-interviu-radu-ciuceanu-fostdetinut-politic-tarii-mele-pentru-care-au-murit-atatia-ii-dorescoameni-curati-15262125, (accessed, April 3, 2017).

10. http://www.ziaristionline.ro/2014/04/16/la-multi-ani-profesoruluiradu-ciuceanu-la-86-de-ani-reperele-mele-pline-de-lumina-sunt-aniide-tinerete-cand-am-pus-mana-pe-arma-si-m-am-impotrivit-regimuluicomunist-si-naimitilor-sai/, (accessed, April 3, 2017).

11. http://www.dailymotion.com/video/xz1j18_prof-roske-despre-raduciuceanu_news, (accessed, April 3, 2017).

12. http://www.dailymotion.com/video/xz1jm4_prof-radu-ciuceanudespre-inchisorile-sale_news, (accessed, April 3, 2017).

13. http://www.dailymotion.com/video/xz1jkr_dinu-zamfirescu-despreradu-ciuceanu_tech, (accessed, April 5, 2017).

14. http://www.dailymotion.com/video/xz1jk0_dr-arh-budisteanu-despreradu-ciuceanu_tech, (accessed, April 5, 2017). 
15. http://www.ziaristionline.ro/2013/04/16/profesorul-radu-ciuceanu-la85-de-ani-marturii-din-inchisori-prea-mult-intuneric-doamne/, (accessed, April 6, 2017).

16. http://roncea.ro/tag/radu-ciuceanu/, (accessed, April 7, 2017).

17. http://roncea.ro/2015/04/17/la-multi-ani-profesorului-radu-ciuceanula-87-de-ani-fotovideo/, (accessed, April 7, 2017).

18. http://jurnalul.ro/cultura/carte/enciclopedia-regimului-comunist-treivolume-din-serie-638718.html, (accessed, April 8, 2017).

19. http://roncea.ro/tag/enciclopedia-regimului-comunist/, (accessed, April $8,2017)$.

20. http://www.ziaristionline.ro/2013/02/15/lansarea-adevaratului-raportasupra-comunismului-din-romania-enciclopedia-regimului-comunistrealizata-de-inst-academia-romana-foto-video-ziaristi-online/, (accessed, April 8, 2017).

21. http://m.cotidianul.ro/radu-ciuceanu-daca-stalin-mai-traia-poatescapam-de-comunisti-107563/, (accessed, April 8, 2017).

22. http://adevarul.ro/news/societate/radu-ciuceanudaca-stalin-mai-traiascapam-comunisti-1_50ad6c777c42d5a66394e057/index.html, (accessed, April 9, 2017).

23. https://lonews.ro/educatie-cultura/22658-prof-dr-radu-ciuceanudoctor-honoris-causa-al-universitatii-ovidius.html, (accessed, April 9, 2017)

24. http://inst-idst.ro/ro/inst/publicatii/reviste/, (accessed, April 9, 2017).

25. http://www.cdep.ro/pls/steno/steno2015.stenograma?ids=5225\&idm=1 19\&idl=1, (accessed, April 11, 2017).

26. http://www.gazetademaramures.ro/zeci-de-sustinatori-pentru-recursulla-demnitate-intentat-de-gazeta-14051, (accessed, April 11, 2017). 